\title{
ПАРКОВКИ ТА СТОЯНКИ В СИСТЕМІ БАГАТОПОВЕРХОВОЇ ЖИТЛОВОЇ ЗАБУДОВИ В М. РІВНЕ
}

\section{PARKING IN THE MULTIFLOOR RESIDENTIAL BUILDING SYSTEM IN THE CITY RIVNE}

\author{
Ліпянін В.А, к.т.н., доц., Стичук В.А., магістр, (Національний \\ університет водного господарства та природокористування, м. Рівне)
}

\begin{abstract}
Lipyanin V.A. Ph.D., Associate Professor, Stychuk V.A., master degree, (National University of Water Management and Natural Resources, Rivne)
\end{abstract}

Анотація. Досліджено можливість влаштування системи парковок та стоянок для автомобільного транспорту у житлових зонах з багатоповерховою забудовою в м. Рівне.

Summary. Currently, one of the most pressing problems of cities is congestion with cars, the number of which is increasing every year. Parking space shortage puts forward the challenge of a comprehensive parking management solution.

So, the main problems with the organization of permanent storage of vehicles are: the lack of space for the organization of permanent storage of vehicles, especially in the areas of the central planning zone; predominance in the structure of places of permanent storage of motor transport garages-boxes and open parking lots, which determines the low efficiency of use of territories; insufficient availability of permanent storage of vehicles. According to regulatory documents in residential areas should provide storage of all residents cars and temporary storage of cars (not less than 15\% of the estimated fleet of cars belonging to residents of the area) so-called "guest parking" for visitors, taking into account the predicted level of automation on settlement period of master plan.

In residential areas with a new multi-story buildings, the priority type of garages for the permanent storage of individual cars should include separately located multistory aboveground, underground and combined aboveground-underground, built-in, including mechanized garages. It is allowed devicing garages built into the first, and basement floors of multi-story residential buildings, as well as open car parks with their subsequent rearrangement in the garage. In terms of residential buildings of up to five floors, it is advisable to provide for permanent storage of cars in low-rise, individually located aboveground, underground and aboveground-underground, including mechanized (automated) garages of the simplest types, as well as in open parking lots. The article conducted a deep analysis and made the necessary calculations for territories with multistorey residential buildings in order to determine the required number of cars for their orderly storage, which meets the modern regulatory requirements.

Ключові слова: житлова забудова, машиномісия, парковки, стоянки.

Keywords: housing development, parking spaces, parking lots, parking lots. 
Вступ. У наш час серед основних містобудівних проблем міст України істотне місце займає ряд питань, які безпосередньо пов'язані з постійним зберіганням транспортних засобів. Сьогодні стрімко зростає рівень автомобілізації, тому проблема відведення території під паркувальні місця та стоянки набуває особливо великого значення. Наявність і зручність паркувальних місць часто являє собою вирішальний критерій у використанні автомобілів у межах міста.

На сьогодні для кожного об'єкту будівництва так чи інакше вирішується питання розміщення паркувальних місць для їх відвідувачів.

У житлових районах 3 багатоповерховою забудовою зберігання автотранспорту здебільшого залишається невирішеним.

Аналіз відомих досліджень. Цій актуальній темі було присвячено наукові та методичні роботи Богацького Г.Ф. [1], Осєтріна М.М. [2], Дьоміна М.М. [3], Рейцена С.О. [4], Щеглова В.А. [5] Ткачука ОА., Стародуб І.В. [6].

Згідно з ДБН Б 2.2-12:2019 "Планування і забудова територій" у житлових районах, мікрорайонах повинно бути забезпечене зберігання усіх легкових автомобілів мешканців, а також тимчасове зберігання автомобілів (не менше $15 \%$ розрахункового парку автомобілів, які належать жителям даного району, мікрорайону), так звані «гостьові стоянки» відвідувачів з урахуванням прогнозованого рівня автомобілізації на розрахунковий період генерального плану.

У житлових районах із новою багатоповерховою забудовою пріоритетним типом гаражів для постійного зберігання індивідуальних легкових автомобілів слід передбачати окремо розташовані багатоповерхові надземні, підземні та комбіновані надземно-підземні, вбудовано-прибудовані, в тому числі і механізовані (автоматизовані), гаражі. Допускається влаштування гаражів, вбудованих в перші, цокольні й підвальні поверхи багатоповерхових житлових будинків, а також відкритих автостоянок із подальшим їх перевлаштуванням у гаражі.

В умовах житлової забудови до п'яти поверхів постійне зберігання легкових автомобілів доцільно передбачати у малоповерхових окремо розташованих наземних, підземних та наземно-підземних, у тому числі й механізованих (автоматизованих) гаражах найпростіших типів, а також на відкритих автостоянках.

При розміщенні об'єктів у межах історичних ареалів найкрупніших, крупних та великих міст, у тому числі при будівництві багатоквартирних житлових будинків, у їх складі рекомендується передбачати влаштування підземних гаражів.

Розміщення боксових гаражів на території житлових кварталів, мікрорайонів багатоквартирної житлової забудови не допускається.

Постановка мети і задач досліджень. У зв'язку 3 наведеними вимогами необхідно провести детальний аналіз поверховості житлової забудови 
та розрахунок необхідної кількості машиномісць, опираючись на існуючу забудову м. Рівне; дослідити можливість оптимального влаштування паркінгів у сельбищних зонах.

Методика досліджень. У житлових районах 3 багатоповерховою забудовою приорітетним типом гаражів для постійного зберігання $\epsilon$ багатоповерхові надземні, підземні паркінги з радіусом обслуговування 700 м, в умовах реконструкції - 1000 м. Згідно цього основного критерію, м. Рівне було умовно поділено на ділянки для влаштування паркомісць $\mathrm{i}$ стоянок 3 радіусом обслуговування 700 метрів, де переважає багатоповерхова забудова. Сельбищні зони з одноповерховою садибною забудовою до уваги не брали, так як на таких ділянках можливе влаштування індивідуальних гаражів.

3 метою отримання кількості машиномісць для територій 3 багатоповерховою забудовою був проведений аналіз існуючої забудови 3 врахуванням перспективи автомобілізації.

Згідно поділу на ділянки, було виділено 11 територій з радіусом обслуговування 700 м (рис. 1) 3 багатоквартирною забудовою і був проведений розрахунок кількості машиномісць для кожної конкретної території.

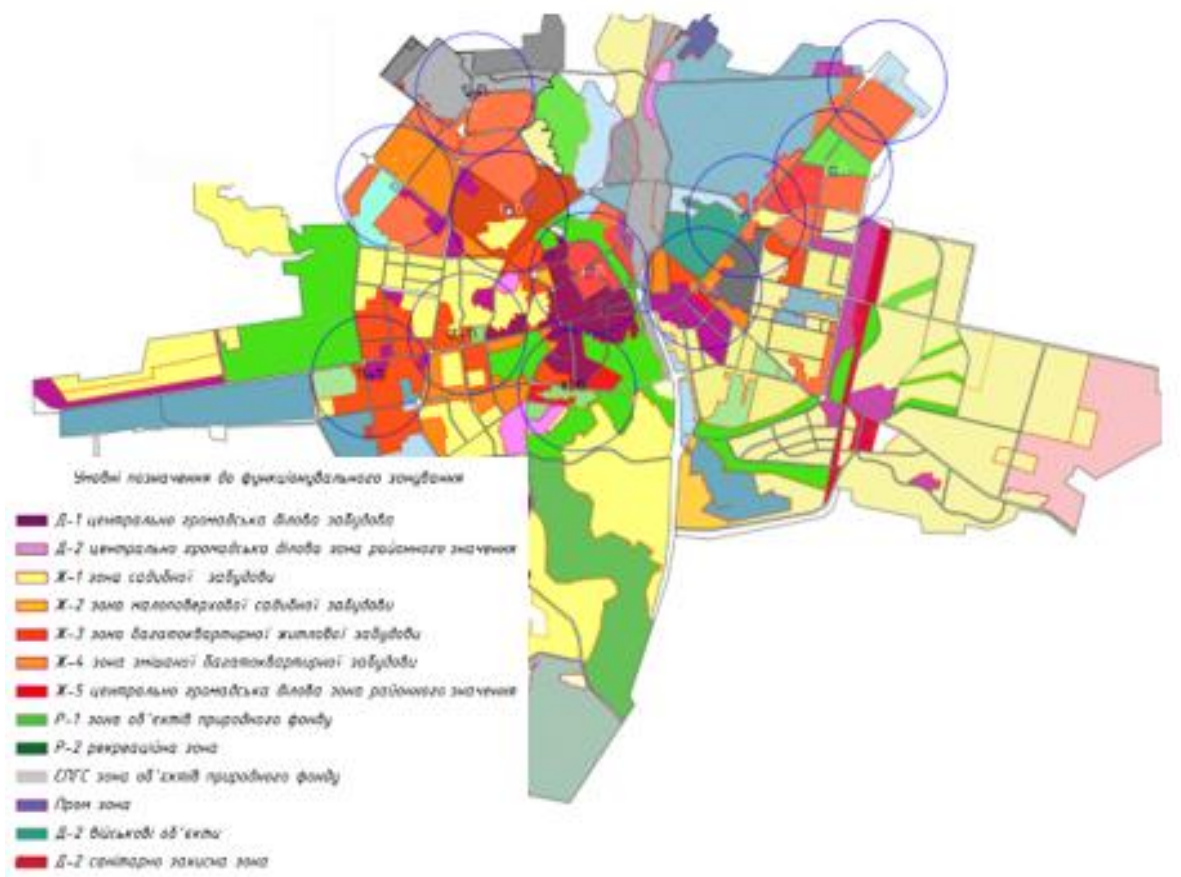

Рис. 1. Схема розміщення ділянок радіусом обслуговування 700 м у м. Рівне 
Ділянка № 1. Ділянка характерна значною кількістю 5-поверхових цегляних будинків серії 1-511 (за типовим плануванням кожна секція має 1 однокімнатну квартиру та 3 двокімнатні), також 9-ти поверховими панельними будинками серії 87-021, двома 14-ти поверховими будинками cepiï 124-87-10.

\section{Гістограма поверховості забудови ділянки 1}

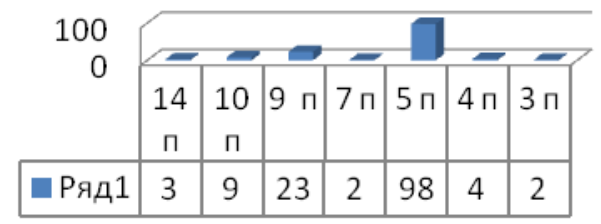

Для ділянки №1 необхідно: 1715+724+168+56+6+32+315=3016 машиномісць. Враховуючи коеф. 0,8 для серединної частини міста: $3016 \times 0,8=2412$ машиномісць.

Ділянка № 2. Ділянка характерна мікрорайонною забудовою панельних будинків від 7 до 10 поверхів П-серії (за типовим плануванням секція має в середньому 1 однокімнатну квартиру та 3 двокімнатних і більше квартири)., невеликою кількістю 5-6 поверхових цегляних будинків серії серії 1-511 (за типовим плануванням даний будинок має 1 однокімнатну квартиру та 3 двокімнатні), також двома 2 поверховими будинками.

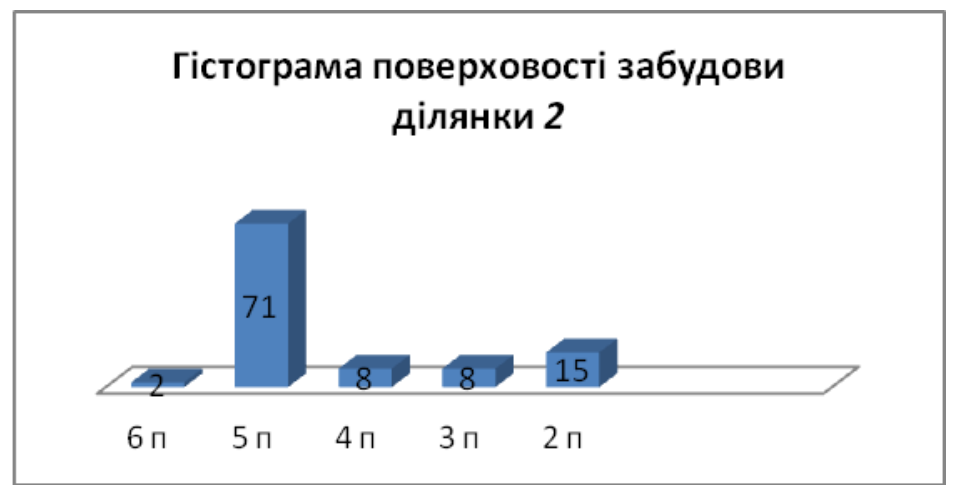


Для ділянки №2 необхідно: $560+3465+144+98+210+8=4485$ машиномісць. Враховуючи коеф. 0,8 для серединної частини міста: $4485 \times 0,8=3588$ машиномісць.

Ділянка № 3. Ділянка характерна змішаною забудовою мікрорайонною забудовою панельних будинків від 9-10 поверхів П-серії (за типовим плануванням секція має в середньому 1 однокімнатну квартиру та 3 двокімнатні і більше квартири), невеликою кількістю 5-ти поверхових цегляних будинків серії серії 1-511(за типовим плануванням даний будинок має 1 однокімнатну квартиру та 3 двокімнатні).

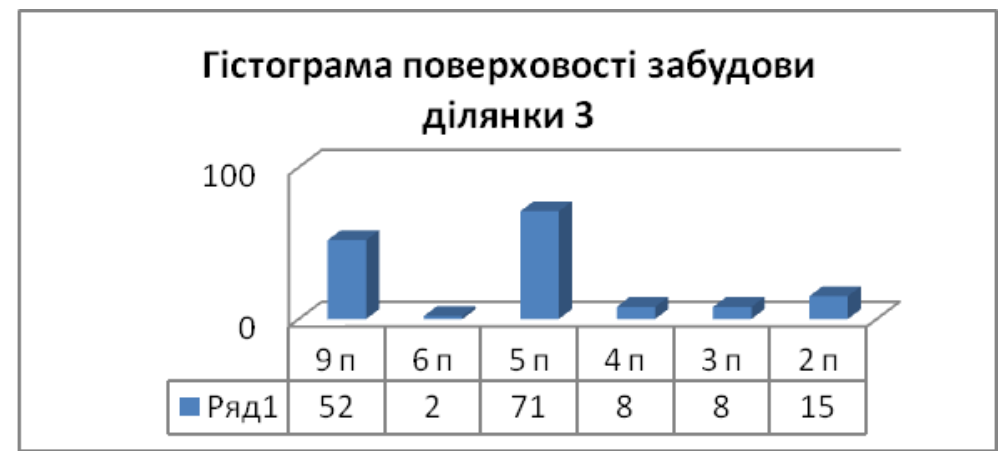

Для ділянки №3 необхідно: 3644+1085+248+80+252=5309 машиномісць. Враховуючи коеф. 0,8: 5309×0,8=4237 машиномісць.

Ділянка № 4. На ділянці розміщується історична частина міста, здебільшого з малоповерховою забудовою 5-ти поверховими цегляними будинками серії Серії 1-511. За типовим плануванням даний будинок має 1 однокімнатну квартиру та 3 двокімнатні і більше.

\section{Гістограма поверховості забудови ділянки 4}

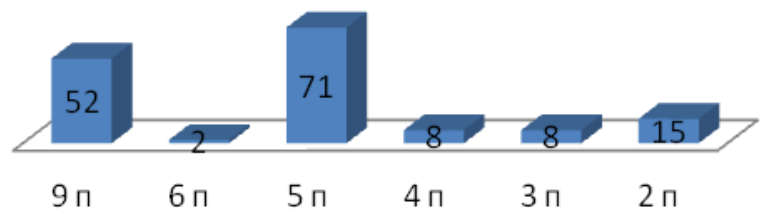

Для 2-х поверхових будинків необхідно: 12+72 = 105 машиномісць. 
Для ділянки №4 необхідно: $1607+1523+42+112+84+105=3473$ машиномісць. Враховуємо коеф. 0,8 для серединної частини міста: $3473 \times 0,8=2779$ машиномісць.

Ділянка № 5. На ділянці розміщується мікрорайонна забудова 35 цегляних та 9 секційних панельних будинків.

За типовим плануванням дані будинки мають 1 однокімнатну квартиру та 3 двокімнатні і більше квартири.

\section{Гістограма поверховості забудови ділянки 5}

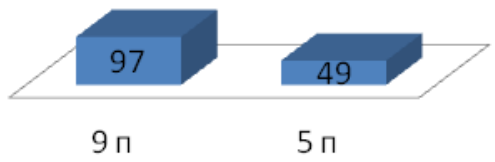

Для 5-ти поверхових будинків необхідно: $123+735$ місць $=858$ машиномісць.

Для ділянки №5 необхідно: 1607+858= 2465 машиномісць.

Враховуємо коеф. 0,8: 2465×0,8= 1972 машиномісць.

Ділянка № 6. На ділянці розміщується мікрорайонна забудова 35 цегляних та 9 секційних панельних будинків.

За типовим плануванням дані будинки мають 1 однокімнатну квартиру та 3 двокімнатні і більше квартири.

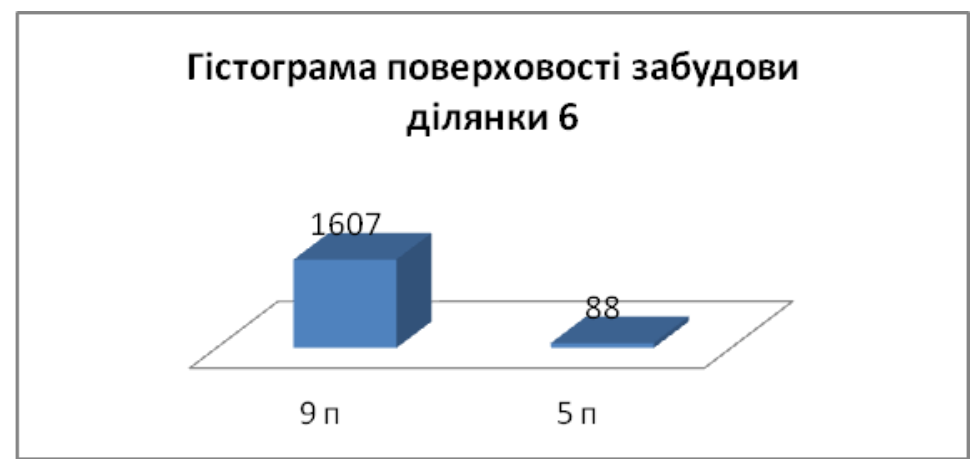

Для ділянки №6 необхідно: 2142+123=2265 машиномісць.

Враховуємо коеф. 0,8 як для серединної частини: $2265 \times 0,8=1812$ машиномісць. 
Ділянка № 7. На ділянці розміщується малоповерхова забудова здебільшого 5-ти поверховими цегляними будинками серії Серії 1-511.

За типовим плануванням даний будинок має 1 однокімнатну квартиру та 3 двокімнатні і більше квартири.

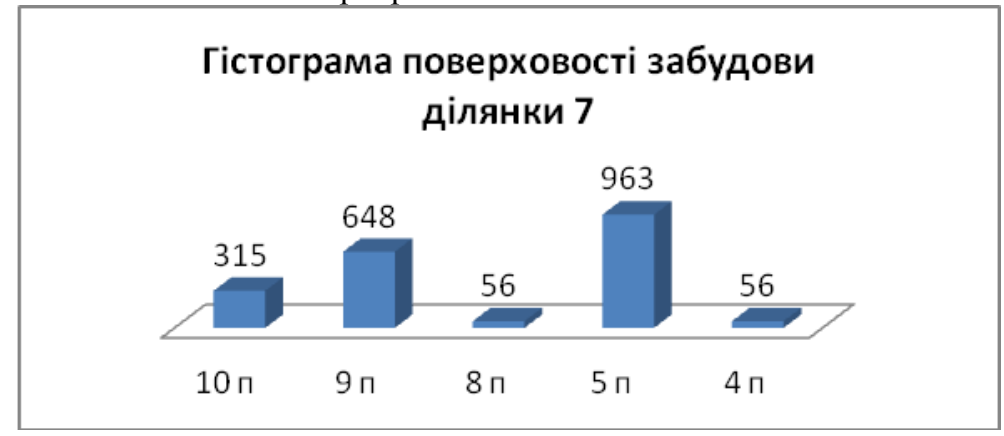

Для 2-х поверхових будинків необхідно: 3+18=21 машиномісце.

Для ділянки №7 необхідно: 1607+88+56+84+84+21=1940 машиномісць.

Враховуємо коеф. 0,8 для серединної частини міста: $1940 \times 0,8=1552$ машиномісця.

Ділянка № 8. На ділянці розміщується частина міста здебільшого 3 малоповерховою забудовою - здебільшого 3-х поверховими цегляними будинками.

За типовим плануванням даний будинок має 1 однокімнатну квартиру та 3 двокімнатні і більше квартири.

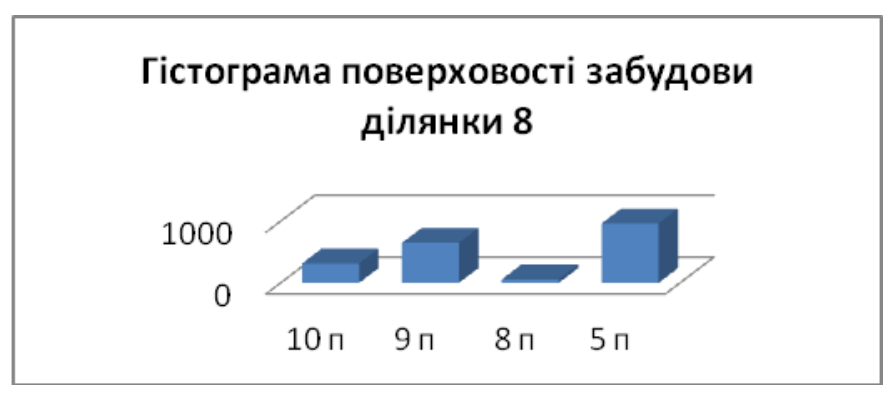

Для 2-х поверхових будинків необхідно: 3+18=21 машиномісце.

Для ділянки №8 необхідно: 31+175+56+399+21=682 машиномісць.

Враховуємо коеф. 0,8 для серединної частини міста: $682 \times 0,8=545,6$ машиномісць.

Ділянка № 9. На ділянці розміщується малоповерхова забудова, здебільшого трьох поверховими цегляними будинками. 
За типовим плануванням даний будинок має 1 однокімнатну квартиру та 3 двокімнатні і більше квартири.

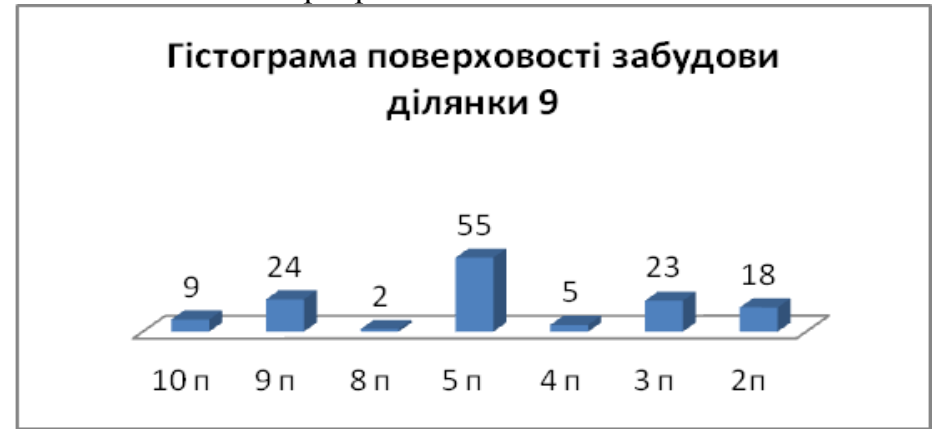

Для ділянки №9 необхідно: 72+756+56+963+56+242+126=2271 машиномісць. Враховуємо коеф. 1 для центральної частини міста: $2271 \times 1=2271$ машиномісць.

Ділянка № $\mathbf{1 0}$. На ділянці розміщуються здебільшого малоповерхова забудова, здебільшого 3 -х поверховими цегляними будинками.

За типовим плануванням даний будинок має 1 однокімнатну квартиру та 3 двокімнатні і більше квартири.

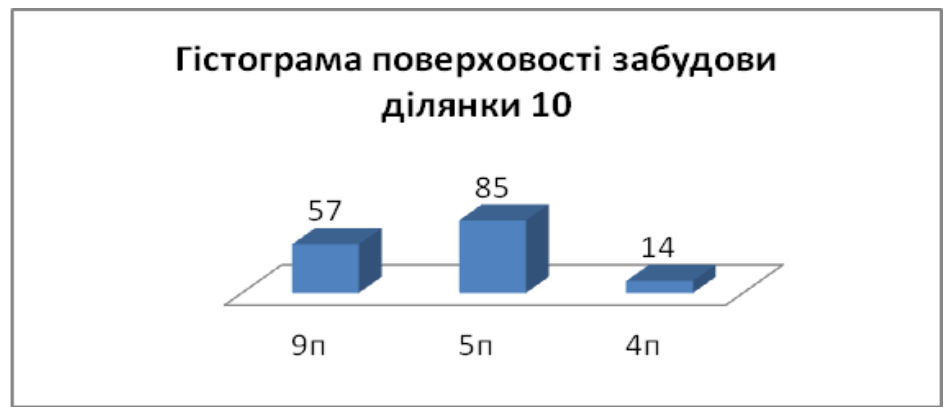

Для 4-х поверхових будинків необхідно: 168+48=216 машиномісць. Для ділянки №10 необхідно: 1796+1488+216=3500 машиномісць. Враховуємо коеф. 0.8: $3500 \times 0,8=2800$ машиномісць.

Ділянка № 11. На ділянці розміщується здебільшого багатоповерхова забудова, здебільшого 9 панельними та 5 цегляними секційними будинками, також двома 14 поверховими будинками. 


\section{Гістограма поверховості забудови ділянки}

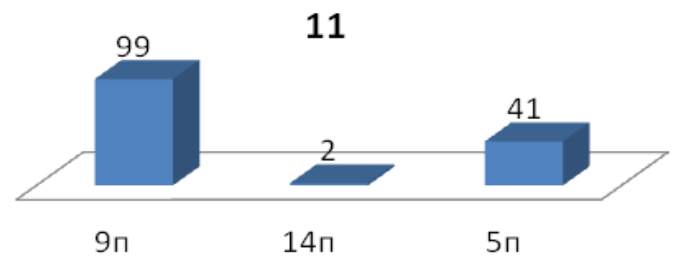

Для 3 поверхових будинків необхідно 4+27= 31 машиномісце.

Для ділянки № 11 необхідно: $31+717+2835+252=3835$ машиномісць.

Враховуємо коеф.0,8: $3835 \times 0,8=3068$ машиномісць.

Результати досліджень. За результатами досліджень було встановлено, що для забезпечення потреби в машиномісцях для жителів, які проживають на досліджуваних територіях, необхідно влаштувати додатково стоянки та парковки на 27792 машиномісця.

Висновки. Ситуація, яка склалась, повинна бути змінена та виправлена шляхом реалізації основних положень, що грунтуються на аналізі світового досвіду організації місць для зберігання автотранспорту:

- у багатьох країнах поширені перехоплюючі парковки та стоянки. Вони розташовуються на периферії міст, поруч зі станціями метро, на в’їздах до міста для того, щоб вранці і вдень залишати автомобіль в надійному, охоронюваному місці $\mathrm{i}$ пересуватись далі містом у громадському транспорті. Вночі перехоплюючі парковки та стоянки використовується для зберігання автотранспорту мешканців, які проживають на прилеглій території. В англомовних країнах цьому поняттю відповідає термін "Park and ride" - "припаркуйся та їдь далі" - i позначається спеціальним знаком "P+R";

- мережу гаражів необхідно розширити відповідно до вимог ДБН Б 2.2-12:2019 за рахунок проведення поступової реконструкції існуючих одноповерхових гаражів із надбудовою над ними 3-5-поверхових механізованих (автоматизованих) гаражів;

- існуючі автомобільні парковки та стоянки реконструювати 3 будівництвом підземних-наземних паркінгів, що дозволить у декілька разів збільшити місткість паркувальних площ;

- при реконструкції території житлової забудови проектувати та будувати внутрішньоквартальні та дворові підземні та напівпідземні гаражі-стоянки під житловими будинками, дворовими територіями, проїздами, враховуючи особливості прокладання інженерних мереж та організації дворових територій;

- заборонити використання території житлової забудови для паркування автомобілів відвідувачами громадських закладів, магазинів, 
офісів, що знаходяться поряд із житловою забудовою, шляхом встановлення відповідних забороняючих знаків;

- здійснювати регулярний контроль за дотриманням громадянами порядку у використанні дворових територій для зберігання та паркування особистого автотранспорту.

\section{References}

1. Bogatsky G.F. Issues of parking of motor vehicles in the complex transport scheme of the city. // Transport and communication routes in cities / Materials republic. scientific-technical Conf. - Alma-Ata, 1971, p.157-160.

2. Osetrin N.N. Choosing a parking system in the city. // Urban planning. Rep. inter. scientific and technical Sat Issue 25.-Kiev: Budivelnik, 1978, S.80-83 (Kiev Scientific Research Institute of Urban Development and Urban Development).

3. Demin N.M. Problems of humanization of the urban environment // Ann. Publishing House of the Moscow Branch of the International Academy of Architecture, 2004, S.24-27.

4. State building codes of Ukraine: Transport structures. Parking lots and garages for cars. DBN B.2.3-15: 2007. - Kyiv, 2007. - 38s.

5. Scheglov V.A. Car parking in urban centers. - M.: City economy of Moscow, 1970. - 209 p.

6. O.A. Tkachuk, I.V. Starodub. Organization of the system of parking and parking in the residential development of the city of Rivne // Urban planning and territorial planning. Issue 37, - Kyiv: KNUBA, 2010, no., P. 489 ... 498.

7. DBN B.2.2-12: 2019. Territory planning and development. - K: Ministry of Regional Development, Construction and Housing and Communal Services of Ukraine, 2019. - 177 p.

\section{Список використаної літератури}

1. Богацкий Г.Ф. Вопросы паркирования легкового автотранспорта в комплексной транспортной схеме города. // Транспорт и пути сообщения в городах / Материалы республ. научн.-техн. конф. - Алма-Ата, 1971, С.157- 160.

2. Осетрин Н.Н. Выбор системы автостоянок в городе. // Градостроительство. Респ. межвед. науч.-техн. сб. Вып.25.-Киев: Будівельник, 1978, С.80-83 (КиевНИИградостр-ва).

3. Демин Н.М. Проблемы гуманизации городской среды // Ежегодн. изд-е Московского отделения Международной Академии архитектуры, 2004, С.24-27.

4. Державні будівельні норми України : Споруди транспорту. Автостоянки і гаражі для легкових автомобілів. ДБН В.2.3-15:2007. - Київ,2007. - 38с.

5. Щеглов В.А. Автомобильные стоянки в городских центрах. - М.: Городское хозяйство Москвы, 1970. - 209 с.

6. О.А. Ткачук, І.В.Стародуб. Організація системи парковок та стоянок в житловій забудові міста Рівного// Містобудування та територіальне планування. Випуск 37, - Київ: КНУБА, 2010, №.., с. 489...498.

7. ДБН Б.2.2-12:2019. Планування та забудова територій. - К.: Міністерство регіонального розвитку, будівництва та житлово-комунального господарства України, 2019. - 177 с. 